\title{
FINANCIAL PERFORMANCE ANALYSIS OF RURAL BANKS IN MANOKWARI: A CASE STUDY OF ARFAK INDONESIA RURAL BANK
}

\author{
Rully Novie Wurarah ${ }^{1) 凶}$, Mona Permatasari Mokodompit ${ }^{2) 凶}$ \\ Universitas Papua
}

\begin{tabular}{|c|c|}
\hline Article & Abstract \\
\hline Information & The purpose of this research is to analyse \\
\hline Receiv & $\begin{array}{l}\text { Manokwari Regency in the period of } 2014-2018 \text { using financial ratios include liquidity, solvency and } \\
\text { profitability ratios. Liquidity ratio is measured using Loan to Deposit Ratio (LDR), solvency is measured using }\end{array}$ \\
\hline Accepted July 2020 & Capital Adequacy Ratio (CAR), and profitability ratio is measured using Net Profit Margin (NPM) and Return \\
\hline Published September 2020 & $\begin{array}{l}\text { on Asset (ROA). The research results shows that in the past } 5 \text { years, the average value of LDR }(113 \%) \text { is too high } \\
\text { which is above } 80 \% \text {, thus the bank does not have enough liquidity to cover any unforeseen fund requirement. }\end{array}$ \\
\hline Keyn & Furthermore, the average value of CAR $(10.67 \%)$ was between the value of $9.5 \%$ and $11 \%$, which indicates that \\
\hline Finan & the bank has enough capital to cushion potential losses and protect depositor's money. As for the average value \\
\hline Rural B & of NPM (39.46\%) and ROA (6.73\%) shows that the bank has a very good ability in generating profits. \\
\hline
\end{tabular}

(C) 2020 Indonesia

\begin{tabular}{lc}
\hline Correspondence Address: & ISSN 2548-9909 \\
Universitas Papua & \\
E-mail: m.mokodompit@unipa.ac.id &
\end{tabular}




\section{Introduction}

Manokwari, as the capital city of West Papua Province, has rural banks as one of the financial institutions that support the economy and development as well as increasing the economic empowerment of the community. Generally, the location of rural bank that is most located close to the community who need financial services is one of the advantages in rural bank industry. Rural banks prioritize a personal approach in providing services in accordance with the characteristics of the surrounding community by giving fast and simple service processes and also by providing products characteristics the community needs, such as flexible amounts and credit terms and simpler administrative requirements.

However, there are some challenges faced by rural bank industry include limited paid up capital, quality and quantity of human resources that are still being improved, governance and competitiveness of rural bank that still needs be improved, expensive fund sources (high cost offunds), and less competitive lending rates due to high overhead costs. Furthermore, the business challenges faced in the industry are in the form of increasingly stringent regulations, policies for channeling people's business credit, industrial revolution 4.0 and digitizing banking services.

Table 1. Growth of Total Rural bank and Rural Bank Offices Based on Location - December 2018

\begin{tabular}{clrrlr}
\hline No. & \multicolumn{1}{c}{ Location } & Total & No. & \multicolumn{1}{c}{ Location } & \multicolumn{1}{c}{ Total } \\
\hline 1 & West Java & 1,056 & 19 & East Kalimantan & 51 \\
2 & Banten & 174 & 20 & Central Kalimantan & 17 \\
3 & DKI Jakarta & 52 & 21 & Central Sulawesi & 47 \\
4 & DI Yogyakarta & 241 & 22 & South Sulawesi & 43 \\
5 & Central Java & 1,594 & 23 & North Sulawesi & 66 \\
6 & East Java & 1,583 & 24 & Southeast Sulawesi & 26 \\
7 & Bengkulu & 12 & 25 & East Sulawesi & 2 \\
8 & Jambi & 32 & 26 & Gorontalo & 8 \\
9 & Aceh & 38 & 27 & NTB & 114 \\
10 & North Sumatera & 140 & 28 & Bali & 322 \\
11 & West Sumatera & 222 & 29 & NTT & 19 \\
12 & Riau & 67 & 30 & Maluku & 20 \\
13 & Kepulauan Riau & 78 & 31 & Papua & 26 \\
14 & South Sumatera & 49 & 32 & North Maluku & 8 \\
15 & Bangka Belitung & 17 & 33 & West Papua & 10 \\
16 & Lampung & 75 & 34 & Others & - \\
17 & South Kalimantan & 34 & & & \\
18 & West Kalimantan & 30 & & Total & $\mathbf{5}$ \\
\hline Source: (F. S. A. R. O. Indonesia, 2019) &
\end{tabular}

Source: (F. S. A. R. o. Indonesia, 2019)
Based on the data in Indonesia Banking Statistics 2018, there are 10 rural banks in West Papua province as of December 2018. However, the development of rural banks in West Papua province in the last 5 years has tended to decline since the level of growth in the value of total assets was only about $0.004 \%$ as of December 2018, and as for the Third Party Funds is $0.061 \%$. The value of Non-Performing Loans to rural banks in West Papua also experienced a significant increase of $3.22 \%$ in 2018 , from Rp27 billion in 2017 to Rp114 billion in 2018 (Province, 2019)

Arfak Indonesia Rural Bank or also known as ARFINDO is a rural bank located in Manokwari Regency West Papua. It has an important role in the community as an economic driver. It has proven to be beneficial for small and medium economic communities since it is easily accessible to them. Although there are currently many microfinance institutions, both banks and non-banks, its existence has gained recognition from the public. Therefore, assessing the financial performance of the bank becomes very important. Not only to give information about the bank's health to managers or other parties but also considering that the banking operations are very sensitive to the country's economic condition (Ottay \& Alexander, 2015).

In order to determine financial performance, the most frequently used method is financial ratio analysis (Handayani, Korompot, \& Hadjaat, 2013). Financial ratio analysis requires financial statement of at least the last two years of the company's operations to be compared (Tanor, Sabijono, \& Walandouw, 2015) The type of financial ratios required in each company is certainly different, depending on its acitivites. According to (Kasmir, 2002) some financial ratios that are considered important include liquidity, solvency and profitability ratios.

Liquidity ratio shows the ability of the company to meet short-term obligations, whereas solvency ratio is the ability of the company to pay long-term financial obligations. As for profitability ratios is the management's return on 
sales and investement (Singh \& Schmidgall, 2002).

Thus, the purpose of the research is to analyse the performance of Arfak Indonesia Rural bank in the period of 2014 to 2018 using financial ratios, include liquidity, solvency and profitability ratios. To determine the liquidity ratio, this research use Loan to Deposit Ratio (LDR) as the measurement. This ratio is able to measure the ability of the bank to refinance the withdrawals that have been made by customers by relying on loans as source of liquidity (Wulandari \& Zulakarnain, 2016). Further, for the solvency ratio, this research uses Capital Adequacy Ratio (CAR). This ratio is one of the most significant current issues in banking which evaluate the amount of the bank's efficiency and stability (Bateni, Vakilifard, \& Asghari, 2014). Lastly, the profitability ratio is measured using Net Profit Margin (NPM) and Return on Asset (ROA) ratios. NPM measures the company's ability to generate net profit, whereas, ROA measure the company's effectiveness in utilizing its assets (Asmirantho \& Yuliawati, 2015). Morover, the following are research question that have been formulated: How is the performance of Arfak Indonesia Rural bank when viewed from a liquidity perspective using LDR, solvency perspective using CAR and profitability perspective using NPM and ROA?

The results of this research are expected to provide information regarding the actual financial condition of Arfak Indonesia Rural Bank in Manokwari Regency within five years. The information can then be used both as an input, as well as a consideration material by internal or external parties of the bank in making business or investement decision (Alamry, 2020)

\section{Methods}

Financial performance analysis essentially aims to determine the company's financial condition by making an assesmenet using comparisons and applicable rules (Tanor et al., 2015). Financial performance can be analyzed from various point a view using various parameters, such as financial ratios. Financial ratio analysis is basically one of a method used to analyze financial performance.

The present research is a case study conducted at Arfak Indonesia (ARFINDO) rural bank in Manokwari Regency, West Papua. It aims to analyse the performance of the rural bank in the period of 2014 to 2018 using financial ratios, include liquidity, solvency and profitability ratios.

The primary data examined is the Bank's financial statement from 2014 to 2018 which have been published on the Financial Services Authority (OJK) website. The bank's financial data is then analysed using financial ratio analysis as follows:

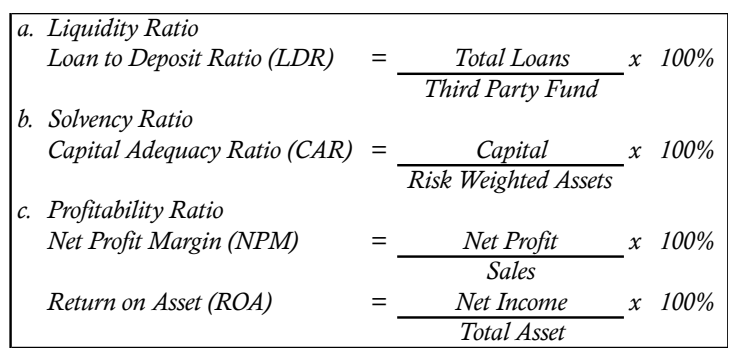

Source: (Kaunang, 2013) \& (Tanor et al., 2015)

Furthermore, the secondary data of the research is in the form of documents related to ARFINDO and also literature/books and articles that are relevant to this research, such as previous studies by Handayani et.al (2013), Kaunang (2013), Tanor et.al (2015), Ottay \& Alexander (2015), that analyze the performance of a company using various parameters. In addition, the research data obtained through observation, interviews and documentation.

\section{Results and Discussion}

3.1 Liquidity Ratio

Liquidity ratio shows the ability of ARFINDO in meeting it's short-term obligation on time, can pay back to all depositors, and can fulfill the credit request submitted without delay. Based on the analysis liqudity ratio using LDR shows that within the year of 2014 to 2018 the value of LDR is between $104 \%$ to $121 \%$ with the average LDR value of $113 \%$ (Table 3). This average value is in the criteria of LDR between $100 \%$ and $120 \%$ which means not good or less 
healthy according to Circullar Letter of Central Bank of Indonesia No.13/24/DPNP/2011 (B. o. Indonesia, 2011). The high LDR value means that the bank may not have enough liquidity to cover any unforeseen fund requirements. The increase of the LDR value was driven by high credit growth from Rp222 million in 2104 to Rp517 million in 2018, while Third Party Fund only grew $1 \%$ to Rp428 million in 2018 .

\subsection{Solvency Ratio}

Solvency ratio shows the ability of ARFINDO in fulfilling its long-term financial obligation. This ratio concerns collateral that measures how far the bank is funded by external parties (creditors). As seen in Table 2, the solvency ratio measured by CAR shows that the CAR value has shrunk significantly by $92 \%$ in 2018 , from $12.47 \%$ in 2017 to $1.05 \%$ in 2018 . This is due to a $92 \%$ decrease in capital in 2018 , while the value of risk-weighted assets only declined by 5\%. Thus, the CAR value in 2018 becomes deflated. However, according to Circullar Letter of Central Bank of Indonesia No.13/24/DPNP/2011, the average value of CAR $(10.67 \%)$ is between the value of $9.5 \%$ and $11 \%$, therefore it is still considered good or healthy. This means that the bank does have enough capital to cushion potential losses and protect depositors's money.

\subsection{Profitability Ratio}

Profitability ratio indicate the ability of ARFINDO in generating profits during a certain period, also aims to measure the level of effectiveness of management in running bank's operational. Using NPM and ROA as the measurement of profitability ratio, it can be seen in Table 3 that the value of NPM within 5 years is ranged between $18.73 \%$ to $46.21 \%$ with the average value of $39.46 \%$. The average value of NPM is in the criteria above 5\% (very good), which according to Circullar Letter of Central Bank of Indonesia No.13/24/DPNP/2011 means the bank is efficient at converting sales into actual profit.

Whereas for the ROA value, it is shown that the values are fluctuated above $1.5 \%$ within 5 years period, which is ranged between $5.68 \%$ to $8.64 \%$ with the average value of $6.73 \%$ (Table 3 ). Thus, the ability of the bank in generating profit is very good according to Circullar Letter of Central Bank of Indonesia No.13/24/DPNP/2011. The greater value of ROA shows the more effective the bank is in using their assets to generate income.

Table 2. Financial Ratio Analysis of Arfak Indonesia Rural Bank from 2014 to 2018

\begin{tabular}{lccccc}
\hline \multicolumn{1}{c}{ Financial Ratios } & $\mathbf{2 0 1 4}$ & $\mathbf{2 0 1 5}$ & $\mathbf{2 0 1 6}$ & $\mathbf{2 0 1 7}$ & $\mathbf{2 0 1 8}$ \\
\cline { 2 - 6 } & $\mathbf{( \% )}$ & $\mathbf{( \% )}$ & $\mathbf{( \% )}$ & $\mathbf{( \% )}$ & $\mathbf{( \% )}$ \\
\hline $\begin{array}{l}\text { Liquidity Ratio } \\
\text { Loan to Deposit Ratio }\end{array}$ & 112 & 108 & 121 & 104 & 121 \\
$\begin{array}{l}\text { Solvency Ratio } \\
\text { Capital Adequacy Ratio }\end{array}$ & 13.88 & 12.16 & 13.77 & 12.47 & 1.05 \\
$\begin{array}{l}\text { Profitability Ratio } \\
\text { Net Profit Margin }\end{array}$ & 46.21 & 43.01 & 45.75 & 43.58 & 18.73 \\
$\quad$ Return on Asset & 8.64 & 6.70 & 6.64 & 6.00 & 5.68 \\
\hline Source: Analysed Primary Data $(2020)$ & & & &
\end{tabular}

Table 3. Descriptive Statistic

\begin{tabular}{lcrrrr}
\hline & N & \multicolumn{1}{c}{ Minimum } & Maximum & Average & Std.Deviation \\
\hline LDR & 5 & 104 & 121 & 113 & 6.853 \\
CAR & 5 & 1.05 & 13.88 & 10.67 & 4.856 \\
NPM & 5 & 18.73 & 46.21 & 39.46 & 10.435 \\
ROA & 5 & 5.68 & 8.64 & 6.73 & 1.029 \\
Valid N (listwise) & 5 & & & & \\
\hline \multicolumn{2}{r}{ Source: Analysed Primary Data (2020) } & & & &
\end{tabular}




\section{Conclusion}

As shown in the results and discussion above, the Bank's average LDR value of $113 \%$ means that the Bank's financial performance according to Circullar Letter of Central Bank of Indonesia No.13/24/DPNP/2011 is considered not good when viewed from a liquidity perspective. In contrary, from solvency perspective, the bank's financial performance is considered good since the average value of CAR is $10.67 \%$. Further, from profitability perspective, the average NPM value of $38.46 \%$ and $\mathrm{ROA}$ value of $6.73 \%$ means that the bank's financial performance is very good.

Therefore, it can be concluded that, the financial performance of Arfak Indonesia Rural bank within the period of 2014 to 2018 when viewed from the perspective of solvency and profitability ratio is considered good, where all the results of the ratio calculation have met the operasional standard performance and health assessment issued by Bank Indonesia for rural banks. Meanwhile, when viewed from the perspective of liquidity ratio, the result is the opposite.

\section{Acknoledgements}

The author would like to thanks to those who have been involved and supportive in completing the research and the article. Hopefully this research can be useful.

\section{References}

Alamry, S. C. M. (2020). Analysis of Financial Statements.

Asmirantho, E., \& Yuliawati, E. (2015). Pengaruh Dividen Per Share (DPS), Dividen Payour Ratio (DPR), Price to Book Value (PBV), Debt to Equity Ratio (DER), Net Profit Margin (NPM) dan Return on Asset (ROA) Terhadap Harga Saham pada Perusahaan Manufaktur Sub Sektor Makanan dan Minuman Dalam Kemasan yang Terdaftar di BEI. Jurnal Ilmiah Akuntansi Fakultas Ekonomi (JIAFE), 1(2), 95-117.

Bateni, L., Vakilifard, H., \& Asghari, F. (2014). The Influental Factor on Capital Adequacy Ratio in Iranian Banks.
International Journal of Economics and Finance., 6(1), 108-116.

Handayani, D., Korompot, N., \& Hadjaat, M. (2013). Analisis Kinerja Keuangan Berdasarkan Rasio Profitabilitas pada PT Bhimex di Samarinda. Publikasi Ilmiah, 1(1), 1-22.

Indonesia, B. o. (2011). Circullar Letter of Central bank of Indonesia No.13/24/DPNP/2011. In. Jakarta.

Indonesia, F. S. A. R. o. (2019). Indonesia Banking Statistics 2018 Vol. 17 No. 01. Retrieved from Jakarta.:

Kasmir. (2002). Bank dan Lembaga Keuangan Lainnya. Jakarta: PT. Rajagrafindo Persada.

Kaunang, S. A. (2013). Analisis Kinerja Keuangan Perusahaan pada PT. Cipta Daya Nusantara Manado. Jurnal EMBA, 1(4), 1993-2003.

Ottay, M. C., \& Alexander, S. W. (2015). Analysis of Financial Statement to Assess the Performance of PT. BPR Citra Dumoga Manado. Jurnal EMBA, 3(1), 923-932.

Province, E. A. R. S. o. W. P. (2019). Regional and Feasibility Needs of Rural Bank Business in West Papua Province. Retrieved from Manokwari:

Singh, A. J., \& Schmidgall, R. S. (2002). Analysis of Financial Ratios Commonly Used by US Lodging Financial Executives. Journal of Leisure Property., 2(3), 201-213.

Tanor, M. O., Sabijono, H., \& Walandouw, S. K. (2015). Financial Statements Analysis in Measuring Financial Performance in PT. Bank Artha Graha International, TBK. . Jurnal EMBA, 3(3), 639-649.

Wulandari, K., \& Zulakarnain, R. W. (2016). The Impact of Solvency Ratio and Liquidity Ratio Toward the Company's Performance Bank Listed on the Indonesian Banking Statistic Period 2010-2015. . Paper presented at the Proceedings International Conference on Economics Business and Social Sciences (ICEBUSS), Malang. 